\title{
Village Fund Allocation Management (Add) in Supporting Rural Development (Case Study of Borokanda Village North Ende District Ende)
}

\author{
Nuraini Ismail ${ }^{1}$, Iriany Dewi Soleiman ${ }^{2}$ \\ ${ }^{1.2}$ Accounting Study Program, Flores University \\ J1. Sam Ratulangi, Ende \\ -e-mail: ${ }^{1}$ nurainiismail100@gmail.com, 2 irianydewi96@gmail.com
}

\begin{abstract}
This research aims to find out the planning process, implementation, and accountability of Village Fund Allocation (ADD) based on the applicable rules. The analysis method used in this research is using qualitative descriptive analysis. The data collected in this study are data on the use of Village Fund Allocation in Borokanda Village, Ende Sub-District from 2016-2018 and data on the planning process, implementation, and accountability of the use of village fund allocation budget in supporting village development. Based on the results of the study shows that the planning process, implementation, and accountability are already based on the applicable rules.
\end{abstract}

Keywords: Village Fund Allocation, Rural Development

\section{INTRODUCTION}

In-Law No. 23 of 2014 on Local Government has been regulated regarding the Implementation of Decentralization System in the State of Indonesia, where the central government gives greater authority to the regions to conduct a series of processes, mechanisms, and planning stages that can guarantee the alignment of development. The basis of thought in the arrangement of villages adopted in Law No. 22/1999, namely diversity, participation, native autonomy, democratization, and community empowerment. This foundation is very contrasting compared to the previously adopted in Law No.5/1979 that stated expressly leads to the uniformity of the form and composition of village government with a national pattern.

The basic basis of village fund allocation (ADD) is Government Regulation No. 72 of 2005 article 1 paragraph 11, Government Regulation No. 43 of 2014 concerning The Implementation Regulation of Law Number 6 the Year 2014 concerning Villages, Regulation of the Minister of Home Affairs Number 37 the Year 2007 concerning Village Financial Management, Circular Letter of the Minister of Home Affairs Number 140/286/SJ Dated 17 the year 2006 concerning Implementation of Village Fund Allocation and Circular Letter of the Minister No.
140/1784/2006 dated October 3, 2006, concerning The Response to the Implementation of Village Fund Allocation (ADD).

The problem experienced by the Borokanda Village government in North Ende District, Ende Regency is the low resources of village government officials in managing government administration (RPJMDes 2013-2019). Based on the results of an interview with Kaur Desa Borokanda Ibu Fitria Sari dated December 12, 2019, especially the financial department has limited human resources ability in managing village fund allocations for example related to the operation and inputting of data into the village financial system (Siskeudes) which every year changes must be adjusted to the latest version, thus causing delays in the creation and reporting of Village Fund Allocation, still weak public participation in the implementation of development. Based on the description above, researchers are interested to take the title "Management of Village Fund Allocation (ADD) in Supporting Rural Development (Case Study of Borokanda Village, North Ende District, Ende Regency")

\section{THE FOUNDATION OF THEORY}

\section{Management}

In general, management is a process that provides supervision on all matters involved in the implementation of policies and the achievement of goals. According to Kila (2016), management is a process, a way of controlling, organizing, organizing, managing, and running things.[1]

\section{Village Development Concept}

The implementation of development is an effort of activities carried out consciously planned and responsible in achieving the goal towards better change, namely welfare and prosperity that is evenly distributed and fair to the people. According to 
Thomas (2013), development is an attempt at the change to be in a better direction than the previous situation, planned consciously to be achieved following the goals based on certain norms.[2] According to Misna (2015), construction is an effort to increase all resources carried out in a planned and sustainable manner with the principle of equitable and equitable use. Village development is all development activities that take place in rural areas, covering all aspects of the life of all communities that are carried out in an integrated manner by developing mutual assistance.[3] Indicators of the success of village development is a real improvement of the living conditions of the community as a whole because development is a process of improvement from a state to a good state

\section{Village Fund Allocation}

Village Fund Allocation or commonly called ADD is a special allocation of villages allocated by the Government through the Local Government (Kabupaten). The main objective is to accelerate the development of village-level both physical development ( pre-facilities) and human resources. According to Sanusi and Djumlani (2014), Village Fund Allocation or ADD is a fund that must be allocated by the District Government for the village, which is derived from the central and regional financial balance funds received from the district whose use is $30 \%$ for personnel and operational expenditures and $70 \%$ for public spending and community empowerment.[4] Granting of Village Fund Allocation (ADD) which is a manifestation of the fulfillment of the village's right to organize village autonomy in order to grow and develop following the growth of the village itself based on diversity, participatory, original autonomy, democratic and community empowerment.

\section{Village Concept}

The village is etymologically derived from Sanskrit, Deca any means homeland, homeland or homeland. According to Nurcholis (2011), the village is an area experienced by several residents who know each other based on kinship and/or political, social, economic, and security interests that in its growth become a unity of the customary legal community so that it creates an inner birth bond between each of its citizens, generally its citizens live from agriculture, have the right to manage their households, and administratively under the Regency /city government. (Nurcholis, 2011).

\section{Village Autonomy}

According to Undan (2013), Autonomy is the freedom to maintain and advance the special interests of the region with its own finances, determining law and self-government. Autonomy is the handover of government affairs to the government to local governments that are operational in the framework of system government bureaucracy. Village autonomy is the original autonomy, round and whole, and is not a gift from the goverrment.[5]

\section{Village Consultative Agency (BPD)}

According to Kusmanto (2013), the village consultative agency(BPD) is an element of village government organizers. Village Consultatory Agency is an institution of democracies in the implementation of village government that can be considered as village parliament. BPD members are representatives of the villagers based on the representation of the filling area is carried out democratically. The number of BPD members is at least five people and at most nine people with concerns about the region, women, population, and financial capabilities of the village.[6]

\section{Village Finance}

Village finance is a right and obligation in the framework of organizing village government that can be assessed with money, including all forms of wealth related to the rights and obligations of the village. According to Nurcholis (2011), village finance is all rights and obligations in the framework of organizing the village government that can be assessed with money, including all forms of wealth related to these rights and obligations.

\section{RESEARCH METHODS}

\section{Types of Research}

The type of research used is qualitative descriptive research. According to Sugiyono (2013), qualitative research is a type of research where the findings are not obtained through statistical procedures or other forms of calculation and aims to reveal symptoms holistically-contextually through data collection from natural settings by utilizing the researcher as a key instrument.[7] 


\section{Research Location}

The location used in this research is in Borokanda Village, North Ende District, Ende Regency.

\section{Data Type}

The types of data used are qualitative data and quantitative data. Qualitative data, namely data obtained in the form of information that supports this writing obtained from the results of interviews, as well as documents/archives in the form of an overview of the village and organizational structure. Quantitative data, namely data obtained from the form of figures during Borokanda Village Office, North Ende District, Ende Regency.

\section{Data Collection Techniques}

Data collection techniques used in this research are:

1. Interview, namely data collection by asking questions directly to the Borokanda village government

2. Observation, namely data collection by conducting observations directly at the location to obtain accurate data.

3. Documentation, namely data collection by collecting village documents and village archives related to the issues to be discussed.

\section{Data Analysis Techniques}

The analytical techniques used in this study were using miles and Huberman models. According to Gunawan (2013), the description of data analysis techniques conducted in this research, namely

1. Data reduction.

Activities summarize, choose the main things, focus on the things that matter, and look for themes and patterns. The reduced data will give a clearer picture and make it easier to do further data collection and search if necessary.

2. Display data/Presentation data

The presentation of data as a set of information is arranged that gives the possibility of drawing conclusions and taking action. Data presentation is used to further improve the understanding of the case and as a reference to take action based on understanding and analysis of the data feed.

3. Decision Withdrawal and Verification

The withdrawal of conclusions is the result of research that answers the focus of research based on the results of data analysis. Conclusions are presented in the descriptive form of research objects based on research studies.[8][9]

\section{RESULTS AND DISCUSSIONS}

Government Regulation No. 43 of 2014 concerning The Implementation Regulation of Law Number 6 the Year 2014 concerning Villages is related to The District/City Government Regulation Number 72 the Year 2005 article 1 paragraph 11 concerning Village Fund Allocation (ADD). The article mentioned that the Allocation of Village Funds is $70 \%$ for the Field of Village Government Implementation and $30 \%$ for community development.

Based on the results of the interview, December 12, 2019, with Mrs. Asmana (Acting Secretary of Borokanda Village) The use of village fund allocation funds intended for the field of village government implementation, where $70 \%$ of the expenditure of village office operational activities, institution operations, and $30 \%$ is used for community empowerment in the field of community development such as youth and sports coaching activities, religious harmony coaching, MFID coaching, standby village coaching. From the results of the interview, it is known that the use of village fund allocation is by Government Regulation No. 72 of 2005 , but the absorption of village fund allocation is still minimal for community development. The following is the allocation of Borokanda village fund allocation in 2018:

Table 4.1

Allocation of Fund Allocation Villages (ADD) In Borokanda Village The year 2018

\begin{tabular}{|c|c|c|}
\hline № & Description & $\begin{array}{l}\text { Borokanda } \\
\text { Village }\end{array}$ \\
\hline $\mathbf{L}$ & $\begin{array}{l}\text { Field of Village } \\
\text { Government } \\
\text { Misapperation }\end{array}$ & Rp 217.680.533,- \\
\hline 1. & Employee Spending & Rp 102.060.000,- \\
\hline 2. & $\begin{array}{l}\text { Shopping for Service } \\
\text { Goods }\end{array}$ & Rp 51.165.533,- \\
\hline 3. & Capital Expenditure & Rp 19.135.000,- \\
\hline 4. & BPD Operations & Rp 8.000.000,- \\
\hline 5. & $\begin{array}{l}\text { RT/RW Operational } \\
\text { Activities }\end{array}$ & Rp 28.320.000,- \\
\hline 6. & $\begin{array}{l}\text { Village Development } \\
\text { Planning Activities }\end{array}$ & Rp 9.000.000,- \\
\hline $\mathbf{L l}$ & $\begin{array}{l}\text { Field of Community } \\
\text { Development }\end{array}$ & Rp 22.900.000,- \\
\hline & Amount & Rp 240.580.533,- \\
\hline
\end{tabular}

Source: Borokanda Village Office, 2018 
Following Law No. 6 of Article 80 states that village development is by the authority given. And what happened in Borokanda Village has done the planning process by the article. According to Mrs. Asmana (Secretary of Borokanda Village), Borokanda village government when preparing village planning refers to the development planning of Manulondo village, firstly develop a Village Medium Term Development Plan (RPM) for 6 years, the second develops a Village Development Plan or so-called Village Government Work Plan (RKP Desa) the period is 1 year. Both of these plans are guidelines in the preparation of the village budget (APB Desa) which is regulated in the Government Regulation in the Preparation of Borokanda village planning, the villagers can play an active role and participate in the preparation. Village planning container in the form of Village Development Planning Deliberation (Musrenbang Desa). The results of the interview are Thursday, December 12, 2019.

According to Mr. Mustafar Haji (BPD Member as well as Indigenous Leaders and Community Leaders) the implementation process in Borokanda Village was pre-planned with planning deliberation activities. Similar to other villages, in Borokanda village, village fund allocation management started from the point of hamlet which was attended by the Village Head, Village Equipment, Village Consultative Agency (BPD), Village Community Empowerment Institute (LPMD) and community leaders in discussing various sectors and fields in each hamlet to find activities that can be funded by ADD per the conditions and potential of the village.

From the point of hamlet, the discovery of work programs from various sectors and fields was discussed through the Village Development Planning Council (Musrenbangdes) which was attended by village devices and community leaders to develop RKPDes following the 2013-2019 RPJMDes, APBDes, RPD, and village profiles. Musrenbangdes is a discussion forum on proposed plans for development activities at the village level based on the principles of Village Community Participation Development Planning ( Interview results, Thursday 12 December 2019)

According to Ibu Asmana(Secretary of Borokanda Village) In the observation in the field it is seen that the Borokanda village government participation from the village community, especially the youth are still less active in the process of implementing development. People who are less active in the implementation of village deliberations cause the implementation of development is still limited. (Interview Results December 12, 2019).

Accountability of Village Revenue and Expenditure Budget is the accountability of the implementation of village budget (APBDes). The operational person in charge of managing the overall allocation of village funds is the Village Head as the Head of the village implementation team. The gradual implementation of accounting principles will support public confidence in the implementation of village development which will eventually be achieved transparency of information received by the community so that the villagers give a positive response to the success of village government programs.

\section{CONCLUSIONS AND SUGGESTIONS}

\section{Conclusion}

Based on the results of the research that has been discussed in the previous section, the author draws the conclusion that:

1. The planning stage has implemented theprinciple of transparency, responsiveness, and participation to reflect accounting principles reflected in Musrenbangdes.

2. The implementation stage in the management of ADD funds in Borokanda Village does not reflect the principle of accountability that has been built, and the lack of participation of the community in the implementation of rural development activities.

3. The stage of accountability is integrated into APBDes and the form of physical excitement given to the community in a transparent and accountable

4. The stage of supervision and evaluation gives more trust to the community because the Village Government provides flexibility for the community to participate in carrying out supervision and evaluate the management of village fund allocation funds.

5. Implementation of Village Fund Allocation is still less effective in terms of implementation time that there are still delays.

6. Lack of participation from the community in the implementation of development. Factors supporting the implementation of village fund allocation in supporting rural development or effectiveness in the field of human resources, environment, and economy. Advice

Based on the results of the discussion and the conclusions, the author suggested several things, among others: 
1.Implementation of Village Fund Allocation runs under the rules to produce better development.

2. All communities should participate in village activities and maintain has; a development that has been implemented.

3. Planning and implementation of rural development should be improved, absorb more Village Fund Allocation (ADD) in the coming years.

4. For the next researcher, it is necessary to conduct research related to community participation in the management of village fund allocation.

\section{REFERENCES}

[1] D. Dalam et al., "DESA MIAU BARU KECAMATAN KONGBENG KABUPATEN KUTAI TIMUR ( Kristina Korniti Kila ),”pp. 1-2, 2016.

[2] Thomas, "Pengelolaan Alokasi Dana Desa dalam Upaya Meningkatkan Pembangunan Di Desa Sebawang Kecamatan Sesayap Kabupaten Tana Tidung," Ejurnal Pemerintah. Integr., vol. 1, no. 1, pp. 51-64, 2013.

[3] F. Kebijakan, A. Dana, and D. Di, "DESA KANDOLO KECAMATAN TELUK PANDAN KABUPATEN KUTAI TIMUR ( Andi Misna )," pp. 80-81, 2015.

[4] D. P. Sanusi and A. Djumlani, "Implementasi kebijakan alokasi dana desa (ADD) di desa Balansiku Kecamatan Sebatik Kabupaten Nunukan," J. Akunt. Publik. Vol. Nomor, vol. 2, no. 3, pp. 1732-1745, 2014.

[5] P. Undan, "Kecamatan Barong Tongkok Kabupaten Kutai Barat ( Studi Tentang Pemilihan Petinggi )," eJournal Ilmu Pemerintah., vol. 1, no. 3, pp. 931-942, 2013.

[6] H. Kusmanto, "Partisipasi Masyarakat dalam Demokasi Politik," JPPUMA J. Ilmu Pemerintah. dan Sos. Polit. UMA (Journal Gov. Polit. Soc. UMA), vol. 2, no. 1, pp. 77-89, 2014, [Online]. Available:

https://doaj.org/article/8f84c9b4e5474466a345d1a1ba52 $70 \mathrm{ab}$.

[7] P. D. Sugiyono, "metode penelitian kuantitatif kualitatif,dan R\&D," Alf. cv., p. 233, 2016.

[8] I. Gunawan, KUALITATIF Imam Gunawan. 2013.

[9] American Journal of Sociology, “済無No Title No Title," J. Chem. Inf. Model., vol. 53, no. 9, pp. 16891699, 2019. 